3-21-1994

\title{
Electrochemical Enzyme Immunoassay Using Sequential Saturation Technique in A $20-\mu l$ Capillary: Digoxin as A Model Analyte
}

\author{
Noriaki Kaneki \\ University of Cincinnati \\ Yan Xu \\ Cleveland State University, y.xu@csuohio.edu \\ Anu Kumari \\ University of Cincinnati \\ H. Brian Halsall \\ University of Cincinnati \\ William R. Heineman \\ University of Cincinnati
}

\section{Sollowexhisadfodfaddiditiah \\ Part of the Analytical Chemistry Commons}

How does access to this work benefit you? Let us know!

\section{Recommended Citation}

Kaneki, Noriaki; Xu, Yan; Kumari, Anu; Halsall, H. Brian; Heineman, William R.; and Kissinger, Peter T., "Electrochemical Enzyme Immunoassay Using Sequential Saturation Technique in A 20- $\mu$ l Capillary: Digoxin as A Model Analyte" (1994). Chemistry Faculty Publications. 187.

https://engagedscholarship.csuohio.edu/scichem_facpub/187

This Article is brought to you for free and open access by the Chemistry Department at EngagedScholarship@CSU. It has been accepted for inclusion in Chemistry Faculty Publications by an authorized administrator of EngagedScholarship@CSU. For more information, please contact library.es@csuohio.edu. 


\section{Authors}

Noriaki Kaneki, Yan Xu, Anu Kumari, H. Brian Halsall, William R. Heineman, and Peter T. Kissinger 


\title{
Electrochemical enzyme immunoassay using sequential saturation technique in a $20-\mu$ l capillary: digoxin as a model analyte
}

\author{
Noriaki Kaneki , Yan Xu , Anu Kumari, H. Brian Halsall and William R. Heineman
}

Peter T. Kissinger

\begin{abstract}
Capillary enzyme immunoassay with flow-injection analysis for digoxin using the sequential saturation technique has been developed. Glass capillary tubes $(10 \mathrm{~cm} \times 0.53 \mathrm{~mm}$ i.d. $)$ with immobilized digoxin antibody were used as the immunoassay reactor. The product of enzymatic reaction, 4-aminophenol, was detected amperometrically. The digoxin and the labeled digoxin binding reaction with the immobilized digoxin antibody were completed in 2 and 10 min, respectively. Digoxin was determined in a $20-\mu$ l sample with a detection limit of $10 \mathrm{pg} \mathrm{ml}^{-1}$ (200 $\mathrm{fg}$ or 260 attomoles) and a 3 orders of magnitude range.
\end{abstract}

Keywords: Amperometry; Enzymatic methods; Immunoassay; Digoxin; Sequential saturation technique

Electrochemical enzyme immunoassays have evolved dramatically during the past decade. These assays are a combination of an immunoassay procedurc with an electrochemical determination of the product of the enzymatic reaction [1]. Electrochemical enzyme immunoassays have low detection limits and a wide range [1-7]. In the initial development of these immunoassays, plastic cuvettes were mainly used as the im- munoassay reaction vessel $[2,3]$. However, the geometry of these cuvettes gives a relatively poor surface area to volume ratio. Since the antibody-antigen reaction for a heterogeneous assay occurs only at the surface, as does the enzyme catalysis, the design of the cuvette is inefficient with respect to mass transport of reactants to the surface and dilution of enzyme-generated product. Recently, the microcapillary immunoreactor, which has a relatively large surface area to volume ratio, has been adapted for immunoassay to improve assay sensitivity and speed [4-10]. Thus far, we have demonstrated this electrochemical capillary immunoassay for the determination of high-molecular-weight compounds (proteins) by sandwich immunoassay, with detection limits as low as 4 zeptomoles [4-6]. 
The objective of the present research was to develop sequential saturation capillary enzyme immunoassay as an analytical method having a low detection limit for low-molecular-weight compounds such as therapeutic drugs. The sandwich immunoassay that we previously demonstrated is not applicable to low-molecular-weight compounds. Digoxin was chosen as a model compound, alkaline phosphatase (EC 3.1.3.1) as the labeling enzyme, and fused silica capillary (10 $\mathrm{cm} \times 0.53 \mathrm{~mm}$ i.d.) as the immunoreactor. Digoxin, a steroidal cardiac glycoside, has a relatively narrow therapeutic range from 0.5 to $2.0 \mathrm{ng}$ $\mathrm{ml}^{-1}$ [11]. Alkaline phosphatase catalyzes the conversion of $p$-aminophenyl phosphate (PAPP) to $p$-aminophenol (PAP), which can be detected electrochemically by oxidation $[3,12]$.

The increased surface area to volume ratio of the microcapillary reactor increases undesirable nonspecific interactions between the enzyme conjugate and components of the immunoreactor other than the antibody paratope. An effort was made therefore to limit access of the conjugate to the silica matrix of the capillary wall by using polyethylene glycol as both a coating and extender for the attachment of the capture antibody.

\section{EXPERIMENTAL}

\section{Apparatus}

The flow-injection amperometric detection system used for this work was a model BAS $\mathbf{4 0 0}$ LCEC system (Bioanalytical Systems, West Lafayette, IN) without a separation column. The thin-layer electrochemical cell had dual glassy carbon working electrodes (only one of which was used), a $\mathrm{Ag} / \mathrm{AgCl}\left(3 \mathrm{~mol} \mathrm{I}^{-1} \mathrm{NaCl}\right)$ reference electrode, and a stainless-steel auxiliary electrode. The injection volume was $5 \mu \mathrm{l}$, and the flow rate was $1.0 \mathrm{ml} \mathrm{min}^{-1}$.

\section{Materials}

Digoxin was purchased from CalbiochemBehring (La Jolla, CA). Digoxin-alkaline phosphatase conjugate (EC3.1.3.1) was from Immunotech (Cambridge, MA). Digoxin antibody in goat serum was a gift from the Centers for Disease Control (Atlanta, GA). The goat antidigoxin antisera was partially purified using a Sephadex G-25-80 $(1 \times 48 \mathrm{~cm})$ column with $0.02 \mathrm{M}$ sodium acetate ( $\mathrm{pH}$ 5.5). p-Aminophenyl phosphate was synthesized using reported procedures [13,14]. Sephadex G-25-80, polyethylene glycol (average mol.wt. 3350), adipic acid dihydrazide, boron trifluoride etherate, bovine serum albumin fraction $\mathrm{V}$ powder (BSA), and D-glucose were from Sigma (St. Louis, MO). 3-Glycidoxypropyltrimethoxysilane, sodium periodate, tris(hydroxymethyl) aminomethane and 1,1'-carbonyldiimidazole were from Aldrich (Milwaukee, WI). 1,4-Dioxane, sodium acetate, Tween 20 , magnesium chloride, and sodium chloride were from Fisher Scientific (Cincinnati, $\mathrm{OH}$ ). Sodium azide was obtained from Eastman (Rochester, NY). Undeactivated fused-silica capillary $(10 \mathrm{~cm} \times 0.53 \mathrm{~mm}$ i.d. $)$ was from J\&W Scientific (Folsom, CA).

\section{Buffers and solutions}

The following aqueous buffer solutions were used. Buffer A1: $0.1 \mathrm{M}$ sodium acetate-acetic acid, pH 5.5. Buffer A2: $0.1 \mathrm{M}$ sodium acetateacetic acid and $0.15 \mathrm{M}$ sodium chloride, $\mathrm{pH}$ 5.5. Buffer A3: $0.1 \mathrm{M}$ sodium acetate-acetic acid, $0.15 \mathrm{M}$ sodium chloride and $0.02 \%(\mathrm{w} / \mathrm{v})$ sodium azide, $\mathrm{pH}$ 4.5. Buffer $\mathrm{B}: 1 \mathrm{M}$ sodium bicarbonate-sodium hydroxide, $\mathrm{pH} 10$. Buffer $\mathrm{C}$ : $0.1 \mathrm{M}$ tris(hydroxymethyl)aminomethane, $1 \mathrm{mM}$ magnesium chloride, and $0.02 \%(\% \mathrm{w} / \mathrm{v})$ sodium azide, pH adjusted to 9.0 by hydrochloric acid. KrebsRinger (K-R) solution: $138 \mathrm{mM}$ sodium chloride, $11 \mathrm{mM}$ sodium bicarbonate, $5 \mathrm{mM}$ potassium chloride, $1 \mathrm{mM}$ dihydrogen phosphate, $1 \mathrm{mM}$ calcium chloride, $1 \mathrm{mM}$ magnesium chloride, 11 $\mathrm{mM}$ glucose, $0.02 \%(\mathrm{w} / \mathrm{v})$ sodium azide and $1 \%$ (w/v) BSA, pH 7.1. Glycidoxypropyltrimethoxysilane (GPTMS) solution: $375 \mu 1$ GPTMS in $35 \mathrm{ml}$ buffer A1. PEG solution: $35 \mathrm{ml}$ of $5 \mathrm{mM}$ PEG in dioxane with $800 \mu \mathrm{l}$ boron trifluoride etherate. 1,1'-Carbonyldiimidazole (CDI) solution: $1 \mathrm{mM}$ $\mathrm{CDI}$ in $6 \mathrm{ml}$ of 1,4-dioxane. Adipic acid dihydrazide (AADH) solution: $4.5 \mathrm{mmol}$ AADH and 8 $\mathrm{ml}$ of $1 \mathrm{M}$ carbonate buffer, $\mathrm{pH} 10$.

Preparation of microcapillary immunoreactor

Microcapillaries $(10 \mathrm{~cm} \times 0.53 \mathrm{~mm}$ i.d.) were used as immunoreactors after the inner surface was modified by covalent attachment of digoxin 
antibody. The antibody was immobilized at the inner surface according to the procedure of $\mathrm{Ku}$ mari [15], which involves covalent attachment via the IgG glycan chains using a polyethylene glycol linker:

(A) Antibody oxidation. The lyophilized antibody was dissolved in buffer A2 and the antibody solution oxidized with $0.4 \mathrm{M}$ sodium periodate for $20 \mathrm{~min}$. The oxidized antibody was desalted by passing through a Sephadex G-25-80 column in buffer A3.

(B) Immobilization. The microcapillaries were pretreated with $1 \mathrm{M}$ sodium hydroxide and $1 \mathrm{M}$ hydrochloric acid and were rinsed with buffer $\mathbf{A 1}$. The capillaries were filled with GPTMS solution and heated at $90^{\circ} \mathrm{C}$ for $5 \mathrm{~h}$. After rinsing the capillaries with 1,4-dioxane, PEG solution was pipetted into the capillaries and incubated at $90^{\circ} \mathrm{C}$ for $0.5 \mathrm{~h}$. After rinsing with 1,4-dioxane, the capillaries were filled with CDI solution and left at room temperature for $15 \mathrm{~min}$. AADH solution was pipetted into the capillaries and incubated at $4^{\circ} \mathrm{C}$ overnight. The antibody was covalently attached to this surface by pipetting the oxidized antibody solution into the capillaries and incubating overnight.

\section{Immunoassay procedure}

The general assay protocol is outlined in Fig. 1. The microcapillary immunoreactor was used in a sequential saturation enzyme immunoassay. Krebs-Ringer solution was used to prepare samples and for blocking and rinsing because it is a suitable perfusion solution in microdialysis sampling, which is one of the intended applications of this assay. The microcapillary immunoreactor was rinsed with $1 \mathrm{M}$ sodium chloride, deionized water and $\mathrm{K}-\mathrm{R}$ solution. Twenty $\mu \mathrm{l}$ of a $1 / 1000$ dilution of enzyme conjugate (digoxin-alkaline phosphatase conjugate) were incubated in the capillaries for various periods of time. The conjugate solution was removed and the capillaries were rinsed with buffer C. Finally, the capillaries were filled with $20 \mu \mathrm{l}$ of substrate (4 mM PAPP) and incubated for $5 \mathrm{~min}$. The contents of the capillary were then injected directly into the FIAEC. The oxidation peak currents of 4-aminophenol at an applied potential of $+300 \mathrm{mV}$ (versus $\mathrm{Ag} / \mathrm{AgCl}$ ) and the corresponding concentrations of digoxin standards were used to construct the calibration curve.

\section{RESULTS AND DISCUSSION}

In the development of an immunoassay method it is important to ascertain the optimum conditions for each stage of the procedure. The sequential saturation enzyme immunoassay required evaluation of the conditions for immobilization and the incubation times of digoxin and labeled digoxin.

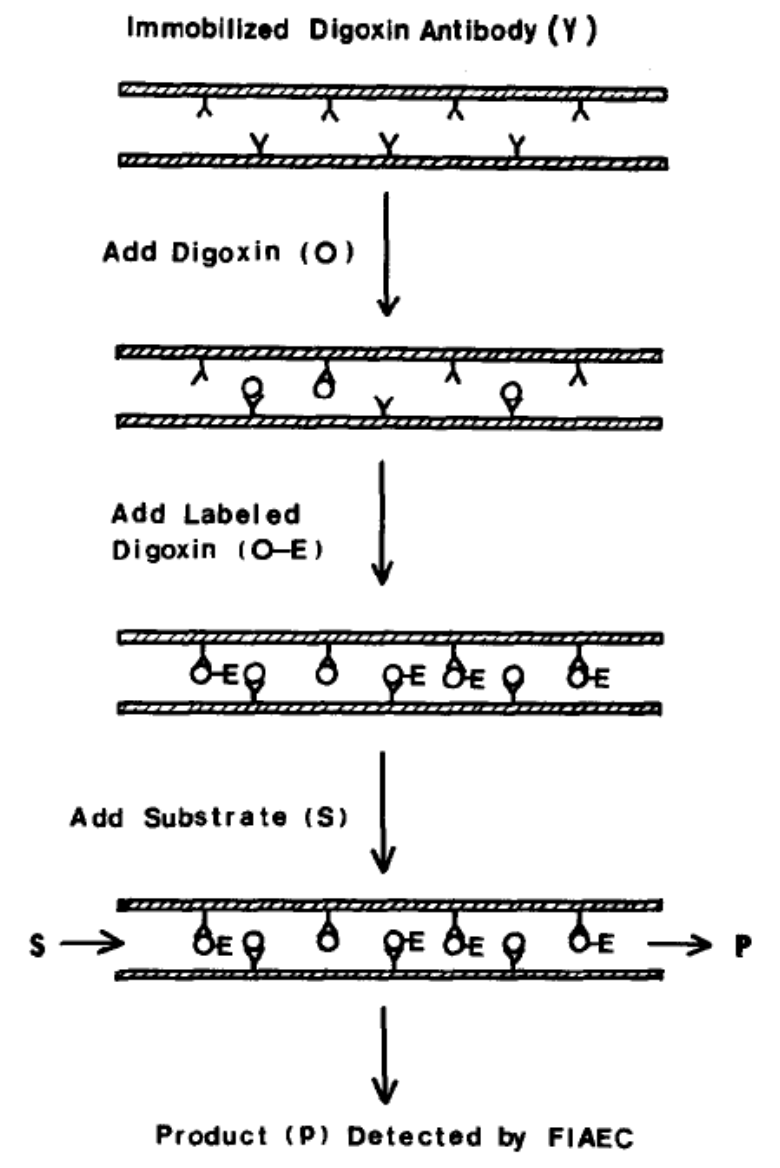

Fig. 1. General protocol for capillary sequential saturation immunoassay. 


\section{Immobilization}

The immobilization of digoxin antibody was carried out by attaching the antibody oxidized with sodium periodate to PEG on the inner surface of the capillaries. Sodium periodate selectively oxidizes the vicinal hydroxyl groups of the oligosaccharide portions of immunoglobulins to aldehyde groups without destruction of the antigen-binding sites $[16,17]$. It has been reported $(18-20)$ that the oxidation of carbohydrates with sodium periodate is dependent on a number of variables including the concentration of sodium periodate, $\mathrm{pH}$, temperature and reaction time. In this work, the antidigoxin immunoglobulins were oxidized with sodium periodate at a concentration of $0.4 \mathrm{M}$ for $20 \mathrm{~min}$ at room temperature at pH 5.5 (buffer A2). The oxidized antibody was immobilized on PEG by coupling the aldehyde groups of immunoglobulin to amino functional groups of PEG. The digoxin antibody was incubated in the capillary at pH 4.5 (buffer A3). The amount of attached antibody was then determined by reaction with labeled digoxin and then with the substrate solution. The result is shown in Fig. 2. There is a sharp increase in the amount of attached antibody in the first 2 days. For convenience, an incubation time of 1 day was chosen.

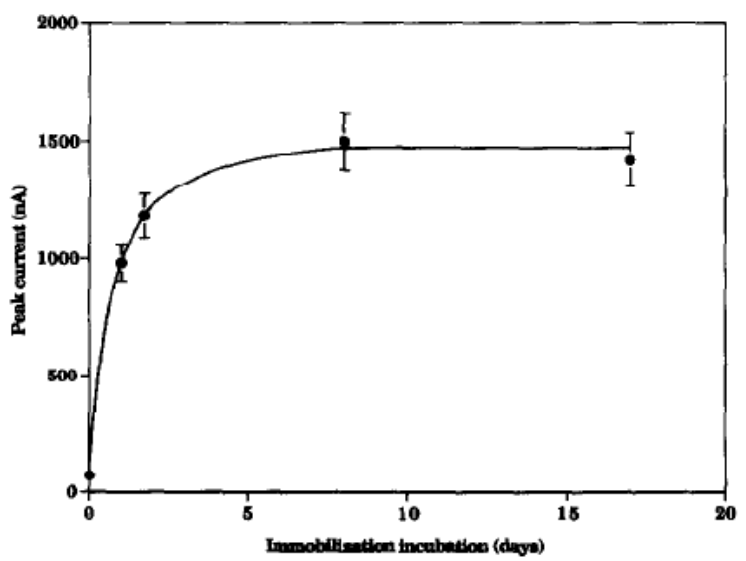

Fig. 2. Effect of incubation time on the immobilization of digoxin antibody. Assay conditions: $12 \mu \mathrm{g} \mathrm{ml}{ }^{-1}$ digoxin antibody concentration, $1 / 1000$ labeled digoxin conjugate dilution, $10 \mathrm{~min}$ labeled digoxin-digoxin antibody incubation time, and $5 \mathrm{~min}$ substrate ( $4 \mathrm{mM}$ PAPP) reaction time.

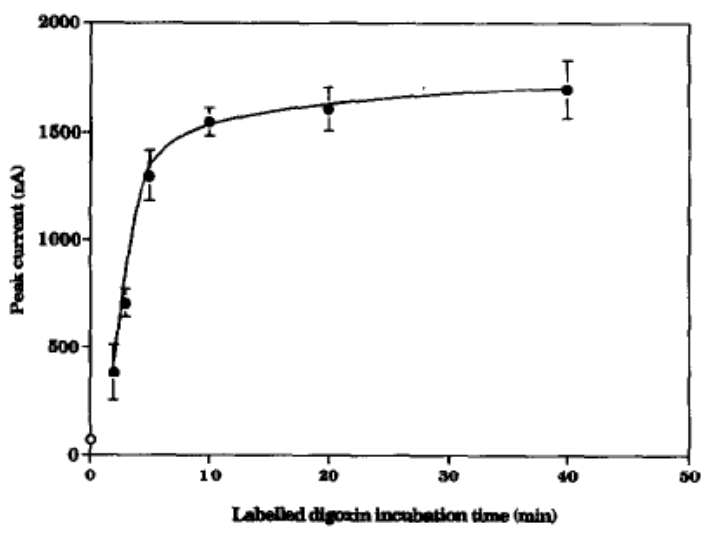

Fig. 3. Effect of incubation time on the binding of labeled digoxin. Assay conditions: $20 \mu \mathrm{g} / \mathrm{ml}$ digoxin antibody concentration, labeled digoxin diluted $1 / 1000,5 \mathrm{~min}$ substrate (4 mM PAPP) reaction time.

\section{Sequential saturation enzyme immunoassay}

Competitive heterogeneous immunoassays are most sensitive when the antigen-antibody reaction is allowed to proceed to equilibrium [21]. Evaluation of the equilibrium incubation times for digoxin and labeled digoxin binding with digoxin antibody for the sequential saturation enzyme immunoassay was necessary to optimize assay sensitivity.

Incubation time of labeled digoxin. Alkaline phosphatase labeled digoxin was incubated in the immunoreactor for various periods of time. Then, enzyme substrate, 4-aminophenyl phosphate, was added and incubated for $5 \mathrm{~min}$ at room temperature. The oxidation peak current of enzyme product was measured by the FIAEC system. As shown in Fig. 3, the binding reaction was complete within 10 min (similar binding reaction times were obtained for tubes made with antibody concentrations of 6 and $\left.12 \mu \mathrm{g} \mathrm{m}^{-1}\right)$. This incubation time for labeled digoxin is much shorter than that (180 min) previously reported for a competitive enzyme immunoassay using conventional immunoplates with LCEC detection [22]. This dramatic reduction is mainly due to the shortened diffusional path from bulk solution to the inner surface of the capillary compared with that of cuvettes $[6,11]$.

Incubation time of enzyme substrate. Alkaline phosphatase labeled digoxin was incubated in the 


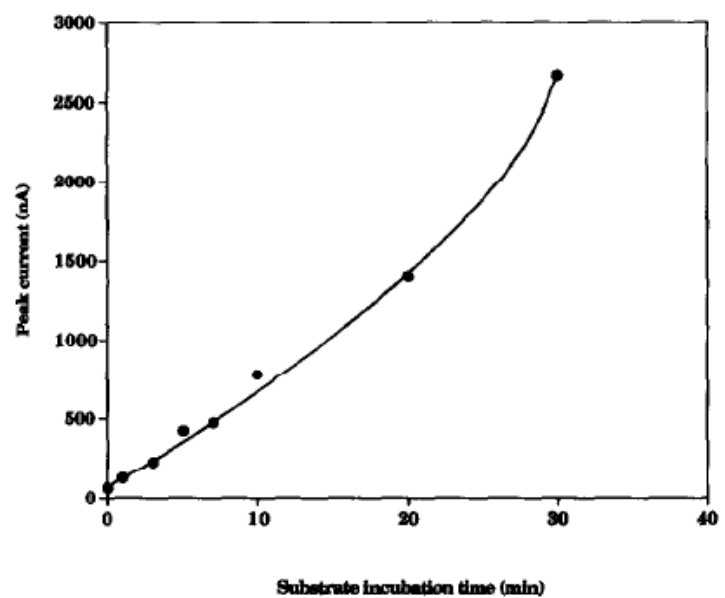

Fig. 4. Plot of peak current vs. substrate incubation time. Assay conditions: $6 \mu \mathrm{g} \mathrm{m}^{-1}$ digoxin antibody concentration, labeled digoxin diluted $1 / 1000$ and $10 \mathrm{~min}$ incubation time.

immunoreactor for $10 \mathrm{~min}$ at room temperature to allow formation of the antibody-antigen complex. After this step, the immunoreactor was rinsed with buffer $\mathbf{C}$ and then incubated with 4-aminophenyl phosphate at room temperature for various periods of time. The result is shown in Fig. 4. In the final assay a substrate incubation time of 5 min was used.

Incubation time of digoxin. The immunoreactor was incubated with $1 \mathrm{ng} \mathrm{ml}{ }^{-1}$ digoxin solution for various periods of time. After rinsing with $K-R$ solution, it was incubated with alkaline phosphatase labeled digoxin for $\mathbf{1 0} \mathrm{min}$ at room temperature. After rinsing with buffer $\mathrm{C}$, the extent of digoxin binding after different incubation times was assessed by the enzyme reaction. The result is shown in Fig. 5. The digoxin binding reaction was completed within $2 \mathrm{~min}$. The time required for the digoxin reaction to reach equilibrium is short because digoxin has a low molecular weight (781). Labeled digoxin has a high molecular weight (70000-120000), so the time required for a labeled digoxin reaction to reach equilibrium is 5-fold longer than that for digoxin.

\section{Assay for digoxin}

The standard curve for a series of digoxin standard solutions is shown in Fig. 6. The assay requires $25 \mathrm{~min}$ for a $20-\mu 1$ sample and has a detection limit of $10 \mathrm{pg} \mathrm{ml}^{-1}$ with a range span-

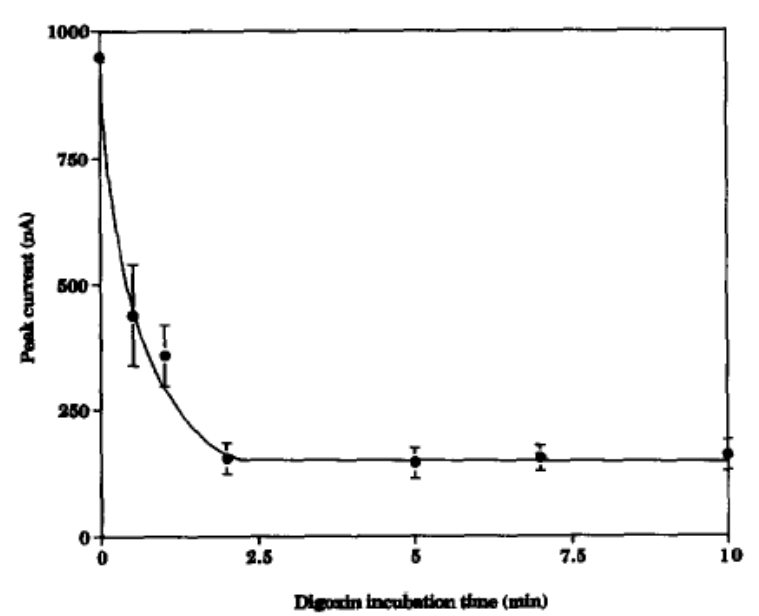

Fig. 5. Effect of incubation time on the binding of digoxin. Assay conditions: $12 \mu \mathrm{g} \mathrm{ml}^{-1}$ digoxin antibody concentration, labeled digoxin diluted $1 / 1000,10 \mathrm{~min}$ incubation time, and 5 min substrate (4 mM PAPP) reaction time.

ning about 3 orders of magnitude. This detection limit is 5-fold lower than that reported for the competitive enzyme immunoassay for digoxin using a polystyrene cuvette reaction vessel [22]. This improvement was mainly due to the large surface area-to-volume ratio of the capillary as an immunoreactor. The main source of imprecision in

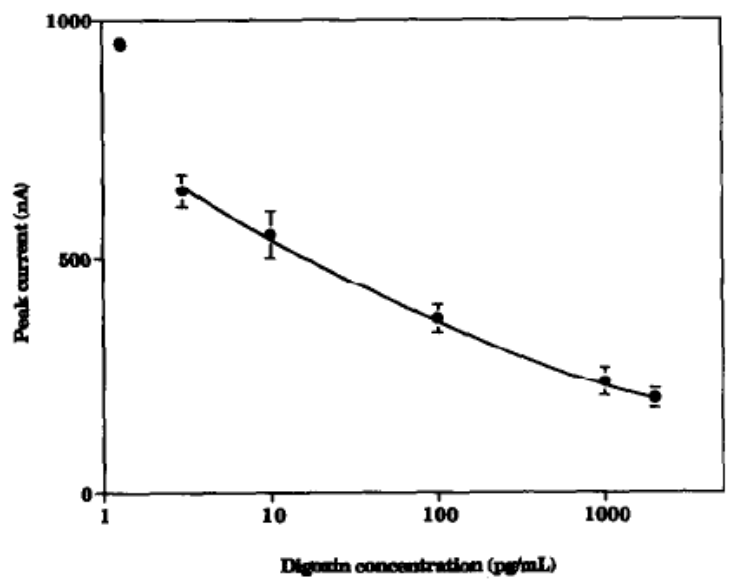

Fig. 6. Calibration curve for digoxin standard solutions. Assay conditions: $12 \mu \mathrm{g} \mathrm{ml} \mathrm{m}^{-1}$ digoxin antibody concentration, 1/1000 labeled digoxin conjugate dilution, 5 min digoxin-digoxin antibody incubation time, $10 \mathrm{~min}$ labeled digoxin-digoxin antibody incubation time, $5 \mathrm{~min}$ substrate (4 mM PAPP) reaction time, and sample solution at $\mathrm{pH} 7.1$. The point in the upper left corner is the zero dose response. 
the assay is reproducibility of the immunoreactor tubes with immobilized antibody, since a different tube is used for each measurement.

\section{Nonspecific binding}

Nonspecific binding of the conjugate to surfaces in the immunoreactor is the most important contributor to the magnitude of the detection limit in immunoassays [4,23]. The problem becomes more acute as the surface area to volume ratio of the immunoreactor increases. The present method was designed specifically to limit nonspecific binding by sterically limiting access of the conjugate to the silica surface of the capillary wall. In addition, although this was not used in the present work, Kumari [15] has shown that addition of PEG and AADH to the conjugate incubation solution further reduces nonspecific binding, presumably by competitive inhibition of interactions between the conjugate and these components of the attachment chemistry.

Although an increased surface area may result in greater nonspecific binding, the shortened diffusional distances dramatically reduce the necessary incubation times. Apart from the operational advantage of this, it serves also to limit the incidence of nonspecific interactions [25].

\section{Conclusion}

The sequential saturation capillary enzyme immunoassay for digoxin had a low detection limit $\left(10 \mathrm{pg} \mathrm{ml}^{-1}\right)$, small sample volume $(20 \mu \mathrm{l})$ and short incubation times ( 2 and $10 \mathrm{~min}$ for digoxin and labeled digoxin, respectively). The detection limit and incubation time for labeled digoxin were 3-fold lower and 6-fold shorter than those previously reported for the competitive enzyme immunoassay for digoxin in serum using a polystyrene cuvette. In terms of amount, the detection limit is $200 \mathrm{fg}(260 \mathrm{amol})$, which is ca. 90 times lower than the detection limit of $19 \mathrm{pg}$ (24 fmol) for the polystyrene cuvettes, which required $375 \mu$ l of sample.

The authors acknowledge Dr. James E. Myrick of the Centers for Disease Control (Atlanta, GA) for providing the digoxin antisera.

\section{REFERENCES}

1 W.R. Heineman and H.B. Halsall, Anal. Chem., 57 (1985) $1321 \mathrm{~A}$.

2 K.R. Wehmeyer, H.B. Halsall and W.R. Heineman, Clin. Chem., 31 (1985) 1546.

$3 \mathrm{Y} . \mathrm{Xu}$, H.B. Halsall and W.R. Heineman, J. Pharm. Biomed. Anal., 7 (1989) 1301.

4 S.H. Jenkins, H.B. Halsall and W.R. Heineman, J. Clin. Immunol., 13 (1990) 99.

5 H.B. Halsall, W.R. Heineman and S.H. Jenkins, Clin. Chem., 34 (1988) 1701.

6 H.B. Halsall, S.H. Jenkins, W.R. Heineman, M.J. Doyle, K.R. Wehmeyer and D.S. Wright, J. Res. Nat. Bur. Standards, 93 (1988) 491.

7 H.B. Halsall and W.R. Heineman, J. Int. Fed. Clin. Chem., 2 (1990) 179.

8 P.A. Nagainis, C.H. Nakagawa, S.L. Baron, S.A. Fuller, H.M. Chandler and J.G. Hurrell, Clin. Chim. Acta, 160 (1986) 273.

9 H.M. Chandler, S.A. Fuller, C.H. Nakagawa, P.A. Nagainis and J.G. Hurrell, Clin. Chem., 33 (1989) 498.

10 M.D. Frutos, S.K. Paliwal and F.E. Regnier, Anal. Chem., 65 (1993) 2159.

11 T.W. Smith and E.J. Haber, Clin. Invest., 49 (1970) 2377.

12 R.Q. Thompson, M. Porter, C. Stuver, H.B. Halsall, W.R. Heineman, E. Buckley and M. Smyth, Anal. Chim. Acta, 271 (1993) 223.

13 L.H. DeRiemer and C.F. Meares, Biochemistry, 20 (1981) 1606.

14 R.Q. Thompson, G.C. Barone, H.B. Halsall and W.R. Heineman, Anal. Biochem., 192 (1991) 90.

15 A. Kumari, M.S. Thesis, University of Cincinnati, 1991.

16 R.K. Yu and R. Ledeen, J. Biol. Chem., 244 (1969) 1306.

17 P.K. Nakane and A. Kawaoi, J. Histochem. Cytochem., 22 (1974) 1084.

18 L. VanLeten and G. Ashwell, J. Biol. Chem., 246 (1971) 1889.

19 E. Ishikawa, M. Imagawa, S. Hashida, S. Yoshitake, Y. Hamaguchi and T. Ueno, J. Immunoassay, 4 (1983) 209.

20 D.J. O'Shannessy and R.H. Quarles, J. Appl. Biochem., 7 (1985) 347.

21 J.C. Standefer and G.C. Saunders, Clin. Chem., 24 (1978) 1903.

22 K.R. Wehmeyer, H.B. Halsall, W.R. Heineman, C.P. Volle and I.-W. Chen, Anal. Chem., 58 (1986) 135.

23 S.H. Jenkins, W.R. Heineman and H.B. Halsall, Anal. Biochem., 168 (1988) 292.

24 R.P. Ekins, in A. Albertini and R.P. Ekins (Eds.), Monoclonal Antibodies and Developments in Immunoassay, New York, Elsevier, 1981.

25 C.H. Pollema, J. Ruzicka and G.D. Christian, Anal. Chem., 64 (1992) 1356. 